\title{
Stopping by Woods on a Snowy Evening' by Robert Frost and 'Because I could not Stop for Death' by Emily Dickinson: A Comparative Study
}

\author{
Dr. Madhushri Kallimani \\ Assistant Professor of English \\ Rani Channamma University \\ Belagavi, India \\ madhushrigkallimani@gmail.com
}

The study of literature is obviously the study of life and death. Literature deals with several nuances of life, death and the philosophies connected. Literature mirrors life and that is how we can realize what life is in a very meaningful way. In literature most of the poetry enlightens the readers through such meanings. This paper focuses on two eminent poets of American literature, i.e. Robert Frost and Emily Dickinson, whose poetry mainly deals with life and death. Both the poets are known for their idiosyncrasies depicting their own style and content. Their poems are philosophical in nature, visualizing nature, relationship, divinity and spirituality. Both the poets were close to nature and spent their lives amidst the beauties of nature. Their poetry is simplistic and honest expressing the daily activities of life.

The Poets

Emily Dickinson admired nature more than poetry and the readers can witness this point in her poetry. To substantiate, 
During her lifetime, Emily Dickinson was known more widely as a gardener perhaps than as a poet. Susan Dickinson's unfulfilled plan for a memoir of her sister-in-law listed "Love of flowers" as Emily's first attribute. Her poetry, for the most part privately "published," was often enclosed in letters pinned together by flowers, or in bouquets that made the poem concealed at the flowers' center and the flowers themselves on message. Even before she wrote poems, Dickinson was engaged in gathering, tending, categorizing, and pressing flowers. After writing poetry became her central preoccupation, cultivating bulbs, plants, and flowers within a portion of her father's land and in the glass enclosure of a conservatory (built just for her), remained a favorite occupation. (p.5)

Likewise, Robert Frost too is another American nature poet. He spent his whole life amidst the fields and nature. He is popularly known for dramatic monologues and for expressing the philosophies of life through poetry. His style is unique with rare content. To illustrate,

The poet/critic Randall Jarrell often praised Frost's poetry and wrote, "Robert Frost, along with Stevens and Eliot, seems to me the greatest of the American poets of this century. Frost's virtues are extraordinary. No other living poet has written so well about the actions of ordinary men; his wonderful dramatic monologues or dramatic scenes come out of a knowledge of people that few poets have had, and they are written in a verse that uses, sometimes with absolute mastery, the rhythms of actual speech." He also praised "Frost's seriousness and honesty," stating that Frost was particularly skilled at representing a wide range of human experience in his poems. (p.4) 
In providing an overview of Frost's style, the Poetry Foundation makes the same point, placing Frost's work "at the crossroads of nineteenth-century American poetry and modernism [with his use of idiomatic language and ordinary, everyday subject matter]." They also note that Frost believed that "the self-imposed restrictions of meter in form" was more helpful than harmful because he could focus on the content of his poems instead of concerning himself with creating "innovative" new verse forms. In Contemporary Literary Criticism, the editors state that "Frost's best work explores fundamental questions of existence, depicting with chilling starkness the loneliness of the individual in an indifferent universe."(p.6)

If Frost was known for his unique style, Emily also had her own candidness and expressiveness. She believed in the American Intellectual movement Transcendentalism which believed that there is a divine spark in every human being. To quote,

The regard Dickinson has won in the little more than a century since her poems introduced her to the world has established her as the most widely recognized woman poet to write in the English language and as an inspiration, both personally and in terms of craft, to modern women writers. As a voice of New England's Protestant and Transcendental cultures in fruitful tension and of the spiritual anxieties unleashed by the Civil War (during which she wrote the great majority of her poems) and as an avatar of poetic modernism, Emily Dickinson now stands with Walt Whitman as one of America's two preeminent poets of the nineteenth century and perhaps of our whole literary tradition. (Crumbley) 
Hence the two poets can be compared as both believed in nature, poetry and modernism and they are certainly the epitomes of American poetry.

The Poems

The poems 'Stopping by Woods on a Snowy Evening' and 'Because I could not Stop for Death' are the masterpieces in American poetry. These poems are evergreen in English literature as the themes are about life and death. The poems also discuss the process of life ending with death. The poem 'Stopping by Woods on a Snowy Evening' is all about how beautiful the nature is, filled with snow in the beautiful hours of dusk. But the poet has to travel to his place before its dark as he has many promises to keep. The metaphysical element in the poem explains how beautiful life is but one also has responsibilities to perform before they die. 'Because I could not Stop for Death' is another beautiful poem expressing death in a very subtle way. It focuses on the journey of death into eternity.

Comparative Elements in the Poems

There are many comparative elements present in the poems which are identical and different. Some of the main elements are journey, nature, life and death. When analyzed the dissimilarities are hardly present. The poems have common factors where one poem reminds the readers of the other.

Journey 
The first and foremost aspect is about journey. The poems are in continuous process and both the poems begin with journey. There are common elements like halts, horse, carriage etc. The differences can be seen in the aspects like pace of the journey which is both slow and fast and if one poem begins with life and ends with death, the other begins with death and ends with immortality.

In 'Stopping by Woods on a Snowy Evening' the poet narrates his journey, how he halts for a moment mesmerized by the beauty of woods in that snowy evening. He knows the owner of the woods but nothing stops him to stand and stare at the beauty which was momentary. He watches the woods fill up with snow. Though he stops there for some time, the poet knows very well that this cannot be eternal. He has to go miles before he sleeps because he has promises to keep. His companion in the journey is a horse. The poet tries to understand the horse's thoughts that it was somewhat strange to stop here without the farmhouse nearby. The line 'And miles to go before I sleep' is repeated and shows how long the journey is. The poem pictures the temporary moments of life. The life is analyzed as a continuous journey ending with death. And the poet has to go a long way still, before the journey comes to an end. He metaphysically renders the meaning of life that in life one has to keep moving. Here the journey is from life to death.

The poem 'Because I could not Stop for Death' also begins with the journey. It's the journey of death towards the eternity. Here too, there is a carriage and horse taking the poet to eternity. Death is the poet's companion. There is a halt explained and how death stops for her as she could not stop. The poet narrates that the carriage carried her and immortality. The journey here is slow as they are not in hurry. The journey includes the activities of life full of sound and fury, and how death overpasses all that. At the end of the journey, the poet realizes that she was 
moving towards the eternity. She understands the horses' heads which were galloping to eternity where she had settle eternally.

Nature

Both the poems have common concepts of nature and the beauty of nature. Poems epitomize the poets' love for nature and the relationship that existed between themselves and nature. The season discussed in the poems is winter and the timing is evening.

In the poem, 'Stopping by Woods on a Snowy Evening' the words like woods, snowy, evening, farmhouse, frozen lake, snowflakes etc., showcase the poet's admiration for nature. The poet enjoys the view of woods filling with snow in the darkest evening. The lakes are frozen because of the snowfall. The only sounds of nature he can hear are the sweep of wind and the falling of snowflakes. He enjoys them amidst the silence of the darkest evening. The line 'The Woods are lovely, dark and deep' represents layers of meaning. At one instance, he is in sublime intoxicated with the beauty of nature. Secondly, the poet realizes that this is momentary and he has to move on as he has responsibilities to perform. Thirdly, the sentence metaphysically denotes the journey and beauty of life or life itself.

The poem 'Because I could not Stop for Death' too includes few elements of nature described in the phrases like, fields of gazing grain, the setting sun passing them, dews drew quivering and chill, house and swelling of the ground. These phrases clearly indicate the presence of nature in the poem. Here too the poet talks about dews and quivering chill which denote season of winter. The phrase 'the setting sun' depicts the evening hour. This also symbolizes the end of life. The house and the swelling of the ground metaphysically mean that 
one has to end life by being one with nature. The belongingness to nature is expressed here in a very subtle way.

Life and Death

The third similarity found in the poems is the notion of life and death. The poems showcase that life and death are like the two faces of a coin. Both are interdependent and influential. One causes the other.

In 'Stopping by Woods on a Snowy Evening' the poet reveals the process of life and how life is full of duties amidst the temporary moments. The poet clearly showcases the realities of life and the beauty, which is short living. To substantiate, in the last stanza, the poet elucidates the philosophy of life in four lines. The lines are as follows.

"The Woods are lovely, dark and deep

But I have promises to keep

And miles to go before I sleep

And miles to go before I sleep".

These lines are evergreen and eternal in the world of English literature as they are open ended with layers of hidden meanings. These four lines render the complete meaning of life and death. The first two lines are all about the life and nuisance attached to it whereas the next two lines depict the death.

The poem 'Because I could not Stop for Death' deals clearly with death. The poet expresses how short the life is and though we are not ready for death, death is ready for us in 
time. Death is inevitable and real, leading mortals into immortality afterlife. Death is personified and is rendered as though he is a sweet companion. The first lines illustrate the point.

\author{
"Because I could not stop for Death - \\ He kindly stopped for me - \\ The Carriage held but just Ourselves - \\ And Immortality".
}

The lines clarify the meaning of life, death and afterlife. She narrates how with ease death accompanies her along the journey and takes her away to the world of eternity. There is a paradox in the last lines of the poem where she explains that 'its centuries and yet feels shorter than a day', which explains the temporariness of life and eternity of death.

Thus, the poems 'Stopping by Woods on a Snowy Evening' and 'Because I could not Stop for Death' travel in the same boat of meaning having lot of commonalities and few dissimilarities. 


\section{Works Cited}

https://www.arts.gov/sites/default/files/Reader-Resources-EmilyDickinson.pdf

http://www.agdc.ac.in/pdf/resource/frost.pdf

https://scholarblogs.emory.edu/eng 190/files/2012/10/Emily-Dickinson.Biography.pdf

https://www.poetryfoundation.org/poems/42891/stopping-by-woods-on-a-snowy-evening

https://www.poetryfoundation.org/poems/47652/because-i-could-not-stop-for-death-479

Robert Frost, "Stopping by Woods on a Snowy Evening" from The Poetry of Robert

Frost, edited by Edward Connery Lathem

The Poems of Emily Dickinson, edited by R.W. Franklin (Harvard University Press, 1999) 